pÿMotivated, resistant, unfortunate and blameworthy Positions constructed for Finnish long-term unemployed individuals through the employability discourse

\title{
Tarkiainen, Laura
}

2021

pÿTarkiainen , L 2021 , ' Motivated, resistant, unfortunate and blameworthy Positions constructed for Finnish long-term unemployed individuals through the employability discourse ' , Nordic Social Work Research, vol. 11 , no. 4 , pp. 361-373 . https://doi.org/10.1080/2156857x.2020.174

http://hdl.handle.net/10138/337981

https://doi.org/10.1080/2156857x.2020.1749457

acceptedVersion

Downloaded from Helda, University of Helsinki institutional repository.

This is an electronic reprint of the original article.

This reprint may differ from the original in pagination and typographic detail.

Please cite the original version. 


\section{Motivated, Resistant, Unfortunate and Blameworthy - Positions Constructed for Finnish Long-Term Unemployed Individuals Through the Employability Discourse}

\section{Laura Tarkiainen ${ }^{\mathrm{a} *}$}

${ }^{a}$ Department of Social Sciences, University of Helsinki, Helsinki, Finland; ${ }^{b}$

E-mail: laura.tarkiainen@ helsinki.fi; postal address: Faculty of Social Sciences, Unioninkatu 37 (POB 54), 00014 University of Helsinki, Finland

Short biographical notes: Laura Tarkiainen is a doctoral student of Social Work at University of Helsinki, Faculty of Social Sciences. Her main research interests concerns discourses on prolonged unemployment, poverty, deservingness and responsibilisation. Laura locates herself within the social constructionist tradition, and has a special interest on discursive methods and questions that sit on the boundary surface of social and labour market policies. 


\title{
Motivated, Resistant, Unfortunate and Blameworthy - Positions \\ Constructed for Finnish Long-Term Unemployed Individuals Through the Employability Discourse
}

\begin{abstract}
In this study I examined the positions Finnish frontline workers constructed for their long-term unemployed clients through the employability discourse. The data consisted of 34 telephone interviews with rehabilitation counsellors working as part of a multi-sectoral team aiming to enhance the employability of unemployed jobseekers who face multiple barriers to attaining a job. In my analysis I identified four main positions: motivated, resistant, unfortunate and blameworthy. Within all of these positions, the responsibility related to employability enhancement was scrutinised. My analysis revealed that frontline workers position themselves as responsible or not responsible for enhancing their long-term unemployed clients' employability depending on how employability or lack of it is constructed and a long-term unemployed individual positioned.
\end{abstract}

Keywords: positioning analysis, long-term unemployment, responsibility, employability, frontline work

\section{Introduction}

In this study, I examine the positions that Finnish frontline workers construct for their long-term unemployed clients through employability discourse. For my analysis, I use interviews with 34 rehabilitation counsellors working on the frontline of the Finnish Multi-sectoral Joint Service Promoting Employment. This joint service provides a wide range of services across organisations and professions, including life skills and job search counselling, health and social services and educational programmes, through which multiple employability enhancement strategies are utilised and practiced. The service plays an important role in encouraging occupants of varying categories to gain 
the status of employable citizen by bringing together different Public Employment Services, Social Insurance Institution rehabilitation services and municipal social and health services.

In Finland, an integrated service has operated in varying form for nearly three decades as a specialised means of helping the long-term unemployed with multiple problems, such as low occupational skills, limited work experience or issues with physical or mental health or substance abuse (see Saikku and Karjalainen 2012; Karjalainen and Saikku 2011; Minas 2014; Rajavaara et al. 2019). In early 2015, the cooperative interagency of the joint service was established and legally set to target long-term unemployed jobseekers whose (re)employment requires integrated service provision (L 1369/2014). Since then, unemployed individuals have been directed to the joint service according to two main criteria: 1) length of unemployment ${ }^{1}$; and 2) a 'need for multi-sectoral support' or integrated service provision (L 1369/2014).

In this study, I illustrate how clients of this service are positioned in frontline workers' interview talk. Thus, I contribute to the literature on the welfare-to-work personnel's discursive strategies related to employability enhancement (e.g. Seale, Buck and Parrotta 2013; Turgeon, Taylor and Niehaus 2014; Agllias et al. 2016; Howard et al. 2018; Romppainen et al. 2010). Here, I approach employability as something that is 'being done' rather than a variable that 'is'; I therefore lean on a critical understanding of what constitutes an employable subject (see Vesterberg 2013; Purser and Hennigan 2017).

\footnotetext{
${ }^{1}$ The unemployed jobseeker has either received basic income allowance for at least 300 days or been unemployed for six months if under the age of 25 or 12 months if over 25 years of age.
} 
In my analysis, I ask:

1) How do frontline workers position long-term unemployed individuals through employability discourse?

2) Within these positions, how are long-term unemployed individuals and frontline workers constructed as responsible for employability enhancement?

In the sections that follow, I first focus on existing literature about employability discourse -especially in relation to frontline practices - and then describe the study's data, aims, methods and analysis. Subsequently, I present the results and reflect on my findings in relation to the existing literature in more detail.

\section{Employability discourse}

The emergence of employability discourse links to a broader policy shift of an 'active society' that expects individuals to take responsibility for their health, fitness and wellbeing as well as be active, flexible and motivated to solve problems related to finding a job (Holmqvist 2009; Rose 2000; Dean 1995; Fejes 2010; Fejes and Berglund 2010). These expectations are actioned through the process of unemployment benefits being earned through participation in tasks associated with being job ready and 'employable' (Purser and Hennigan 2017). Hence, employability discourse impacts everyday frontline practices of activation programmes (Garsten and Jakobsen 2004; Diedrich and Styhre 2013).

Frontline workers in activation are responsible for assessing, monitoring and supervising unemployed people through an array of techniques designed to enhance employability by imparting appropriate skills, orientation and attitudes (McDonald, 
Marston and Buckley 2003, 499). These include individual action plans, careers advice and self-evaluation instruments that aim to encourage employability and selfdevelopment (Garsten and Jacobsson 2013). Employability enhancement can, for example, be practiced by teaching 'soft skills' and advising on language use, job applications and attitude to work (Broughton 2003).

From previous research, frontline workers' interpretation and implementation of activation differs according to how they construct a client's willingness and employability (Nothdurfter 2017). In their encounters, clients may be assessed by their perceived job readiness, remoteness from the labour market and general attitude to work, as well as their body language and demeanour, in particular how pleasant, amenable and grateful they appear to be (Rosenthal and Peccei 2006; Maynard-Moody and Musheno 2003; Lipsky 2010). For example, according to Haikkola's (2019) results young Finnish unemployed people are expected to possess skills such as motivation, activity and self-direction in order to achieve an active designation of a morally worthy unemployed person in everyday encounters with the Public Employment Services. Haikkola's study, however, focused on the service stream intended for clients who were perceived to only need skills enhancement before entering the labour market (in comparison to long-term unemployed clients with multiple problems).

Implementing activation policies includes informing, enabling, convincing, persuading and disciplining clients (Caswell et al. 2017, 193). Marston, Larsen and McDonald (2005) have identified three types of authority in activation - empathetic, pedagogic and coercive - which are invoked depending on whether a person is interpreted as being a 'good' or a 'passive' job seeker. Empathetic authority is used to motivate unemployed clients to become enthusiastic, while pedagogic authority is applied when an unemployed person appears to have a knowledge or skills deficit that 
can be fixed through teaching and instruction. Coercive authority is applied when the empathetic and pedagogic forms fail (see Agllias et al. 2016).

Previous studies have also identified individualistic and structural explanations that frontline workers use when constructing their client's, as well as their own, role in activation. By placing blame and personal responsibility on their clients, frontline workers may also seek to represent themselves as hard-working, deserving, middleclass subjects (Turgeon, Taylor and Niehaus 2014; Howard et al. 2018; Purser and Hennigan 2017; Agllias et al. 2016). In contrast, structural explanations can portray clients as facing legitimate social problems and therefore deserving of consideration from others (Seale, Buck and Parrotta 2013). When frontline workers construct their responsibilities under an active labour market paradigm, narratives of worthy or undeserving citizens and good or bad caseworkers are illustrated (Møller and Stone 2013).

Clients also contribute to negotiations around employability by positioning themselves as 'un/employable' (Eskelinen, Olesen and Caswell 2010, 336-337). As such, employability assessments may lead to self-presentations that constitute 'good' and 'active' approaches to activity encounters; it is vital for service users to convince the bureaucratic gatekeepers that they are actors deserving of care and services (Woolford and Nelund 2013). Previous studies on employability enhancement programmes have, for example, focused on how the unemployed are expected to convey an appropriate aesthetic and embodied performance of job readiness as an indication of their deservingness as presentable, employable individuals with proper tastes (van den Berg and Arts 2019; Cummins and Blum 2015).

\section{Data}


In this study data were drawn from a larger research project that deals with the Finnish Multi-sectoral Joint Service Promoting Employment vis-à-vis its governance and frontline practice. This project was conducted in collaboration with the University of Helsinki (Faculty of Social Sciences) and the National Institute for Health and Welfare.

Data for this study were collected through semi-structured, voluntary telephone interviews with 34 Social Insurance Institution's rehabilitation counsellors who deliver rehabilitation services for unemployed jobseekers within the joint service. Three researchers conducted the interviews, including myself. The interviews were conducted between December 2016 and January 2017. Each interview lasted from 26 minutes to 1 hour and 20 minutes, resulting in a total of 25 hours and 47 minutes of recorded material. The tape-recorded material was then transcribed verbatim in full, resulting in 405 pages of transcribed data.

The vast majority of the potential participants were interviewed, considering that in total 42 rehabilitation counsellors worked at the Multi-sectoral Joint Service Promoting Employment at the time of interviewing. The interviewees had varying educational backgrounds and years of work experience within the joint service, representing a mix of professional identities. However, the vast majority of the interviewees possessed rehabilitation, healthcare and nursing degrees and, in average, the interviewees had been employed in their roles for 4.5 years. 27 counsellors worked at the joint service part-time and 8 full-time. 23 of the counsellors met clients one-byone, whereas 6 counsellors met their clients only as part of a multi-sectoral team. One counsellor only consulted the other professionals of the multi-sectoral team and did not have any face-to-face interaction with the clients. By doing telephone interviews, we reached interviewees from across Finland, from Helsinki to the northern parts of the country. Hence, we were able to draw a general view of the Social Insurance 
Institution's rehabilitation counsellors' nationwide role within the Finnish Multisectoral Joint Service Promoting Employment.

Interview questions focused on the interviewees' experiences working within the joint service, their opinions regarding the service and the rehabilitation services in particular and reflections on their clientele as well as professional practices related to providing integrated services as part of a multi-sectoral team. In addition, interviews included two questions related to clients' motivation since 'motivating' unemployed clients is a legally set task for frontline workers in this specialised integrated service $(\mathrm{L}$ 1369/2014). These questions were formulated to gain better understanding of how policy agenda related to 'motivating' unemployed people with multiple and complex problems was coped with at the frontline. I understand that the interview questions themselves invited talk on long-term unemployed clients' motivation and personal attributes. As such, the interviewees used a variety of ways to describe their clients through culturally available explanations - some resisted making generalisations, and others used lengthy descriptions when talking about their clients and their employability.

After going through the data, the data were analysed by applying the method of positioning analysis in order to grasp the ways in which long-term unemployed individuals were constructed and positioned within the interviewees' talk. Regardless of the possible disadvantage due to the lack of non-verbal cues and potential contextual data, the chosen data collection method suited discursive analysis of interview talk (for similar experiences, see, for example, Turgeon, Taylor and Niehaus 2014). The same data, however, have been analysed in terms of their content, producing alternative interpretations of the material (Heino and Tarkiainen 2019). 


\section{Method}

The study employs the method of positioning analysis. Generally, positioning refers to the process in social interaction whereby individuals are produced through various discursive practices (Davies and Harré 1990). By adopting a stance within a discourse, individuals position themselves and others in relation to that stance: for instance, one can be positioned as powerless or powerful, confident or apologetic or dominant or submissive (Harré and van Langenhove 1991; van Langenhove and Harré 1999). Both intentional and tacit positions are relational, since positioning someone in specific ways means that someone else is positioned relative to that person (van Langenhove and Harré 1999).

Positioning analysis pays close attention to the ever-shifting local moral order of rights, duties and obligations (van Langenhove and Harré 1999). Therefore, positions can be viewed as loose sets of rights and duties limiting the possibilities of action and action repertoires (Davies and Harré 1990; van Langenhove and Harré 1999). Thus, in my analysis I focus on interviewees' talk that positions long-term unemployed individuals and frontline workers as agents of employability enhancement.

Specifically, in my analysis I pay close attention to the question of the responsibility of an occupant of a particular position. Ethically, I understand that the interview setting in itself involves forced and deliberated positionings of agents, including both moral judgements of behaviour and an invitation to positioning (van Langenhoven and Harré 1999; Raitakari et al. 2015). Therefore, the interview data used in this study carry limitations, since participants assume specific roles and may present themselves and others in particular for the purposes and contexts of the interview. 


\section{Analysis}

Initially, I examined the data in their entirety, coding them inductively. Then, I identified the dominance of the discourse of employability. For the next stage of the analysis, I focused on all data passages in which long-term unemployed individuals were mentioned and collected the extracts in a separate file, resulting in 37 pages of transcribed data. Thereafter, the data extracts were first grouped into loose themes and re-read again in closer detail.

After looking at the data more closely, I utilised the method of positioning analysis. As a result, I identified four main positions for further analysis. The identified positions and, consequently, the responsible actor of employability enhancement shifted during the course of the interaction. Few interviewees used exclusively one position throughout the interview when speaking about their long-term unemployed clients' employability. However, the vast majority of the interviewees employed varying positions in their discourse, occasionally in a contradictory manner. These accounts also included additional - less frequently elaborated upon - positions, such as scared, aggressive and privileged. Yet the majority of the positions were constructed and contrasted in relation to their counterparts. The data included both the implicit and the explicit positions; in my analysis I provide examples of each.

After identifying and naming the four key positions, I focused on the second stage of my analysis, in which I paid special attention to how the responsibility for employability enhancement was expressed within each position. My analysis reveals that interviewees not only position the object of their talk - that is, the unemployed individuals - but also themselves as responsible or not responsible for enhancing their clients' employability. 


\section{Results}

I identified four positions - motivated, resistant, unfortunate and blameworthy - in my analysis, each of which involve varying levels of responsibility and activity amongst the long-term unemployed individuals and frontline workers as responsible actors. In what follows, I discuss each of the positions in further detail. I chose eight extracts for further analysis, and I translated them from Finnish into English.

The motivated and the resistant positions appeared most often in the interviews, whereas the unfortunate and the blameworthy positions were employed less frequently. Typically, the interviewees started by positioning most of their clients as motivated. As soon the motivated position was introduced as an ideal-type, other positions were constructed in relation to it. The main findings are collected in table 1. I begin my analysis by describing the most frequently used position.

< insert table 1 here >

\section{Motivated}

The first position constructed through the employability discourse was the position of a motivated long-term unemployed individual. This position constructs a work-lifeorientated individual who can transform his or her attitudes, wishes and goals in relation to a labour market. Within this position, the long-term unemployed individual is ready for a state of development and displays a self-directed attitude in order to gain or maintain his or her employability through different activation and educational measures and skills enhancement despite difficulties entering the labour market.

In most cases an individual occupying the motivated position was constructed in opposition to its counterpart. Therefore, I analyse extracts that involve the positions of both the motivated and the non-motivated long-term unemployed individual. According 
to the interviewees, some clients need special support to build their confidence and generally enhance their employability. But, in order to receive help and guidance, some level of motivation is required, as seen in the following extract:

If I'm giving you a cold estimate, at least 80 per cent are motivated. They want to study, so they will get a job. They will get a better status in the labour market, because they want it. The clients' situations are often stuck, they are bored with it and they want to move on with their lives. Those clients who have no motivation, they won't actually - they won't necessarily stay here in this [joint] service for long. Because here, one needs to have the direction towards a working life. That is the prerequisite for this service. (Interview 4)

In the extract above, the vast majority, 80 per cent, of the long-term unemployed clients is positioned as motivated. The interviewee participates in creating an ideal client who is actively willing to set labour market-oriented goals and upskill by reflecting upon his or her situation through 'a new perspective' with an open-minded attitude and a genuine will to gain employment. The motivated client is 'forward-looking' (see also Arts and van der Berg 2019) in his or her current stagnant situation and, therefore, wants to overcome the barriers that hamper employability. In this extract, the individual's motivation to employability enhancement is potrayed as 'prerequisite', leaving the frontline workers with limited responsibility for employability enhancement.

Within the motivated position the unemployed individual has the right attitude with regards to activation goals and measures set by frontline workers and employability programmes. In most of the interviews, the preferable attitude is linked to job-readiness, as seen in the extract below:

Let's say that a 50-year-old construction worker has been away from the labour market due to back pain, but they previously had a lengthy work history, the rules of working life are in place and there is no substance misuse or other such things. So it is very clear that we complete the occupational rehabilitation. It is known that 
they have a lengthy working history, they are successful, they are motivated and they know the rules of working life. So then it creates a reasonable course of action. Appropriate, because it leads to something. And of course the client knows they can. But then there are those who are very far away [from the labour market]. Those who don't really have any work history, have very weak resources and those who think that one can go somewhere for two hours once a week. So it is really difficult to think of a work life because it is so far away. (Interview 31)

In the extract above, the interviewee is using occupational rehabilitation as an example whilst constructing both an employable and an unemployable, motivated and nonmotivated long-term unemployed client in her discourse. In this extract, the motivated position is constructed through a comparison to someone who is further away from the labour market and is negatively influenced by substance abuse and mental health problems. Thus, persons in the motivated position is close to - and has had contact with - the labour market, perceives themselves as job-ready, is potentially productive and easy to employ. In the extract the frontline workers' responsibility and the course of action are portrayed as 'clear' due to job-readiness and correct attitude of the individual in the motivated position.

However, when creating the motivated position, the interviewees emphasise that motivation may not necessarily lead to success in a highly competitive and changing labour market due to the lack of any real job opportunities and other structural inequalities and explanations contributing to unemployment. Nevertheless, one is preferred to possess or adopt a motivated attitude even though different employability measures are described during interviews as less encouraging due to their weak access to a job. Within the motivated position, the long-term unemployed individuals and frontline workers are described as jointly responsible. Therefore, the employability enhancement is shared to a certain extent. Frontline workers (i.e., the interviewees) and employability programmes have the responsibility to encourage and enable the activity 
of a motivated long-term unemployed individual - that is, to motivate a person to become employable by providing support, sufficient information, time and appropriate opportunities for employability enhancement. However, within the motivated position the responsibilisation of an individual is by no means absent because a particular attitude and a level of hope are expected from the long-term unemployed individual.

\section{Resistant}

The second position constructed through the employability discourse is that of a resistant long-term unemployed individual. This position involves non-ideal activity, in particular, a non-commitment to or non-acceptance of work-oriented employability goals, not showing up and/or avoiding responsibility. In this position the unemployed individual does not show a strong interest in the employability measures nor comply with frontline workers' agenda of employability enhancement. Thus, in this position, the unemployed individual refuses to adapt to existing labour market demands or may wish to pursue unrealistic employment goals, is oriented to retirement and/or has a weak association with the labour market.

The extracts providing examples of the resistant position reflect varying forms of unemployed individuals' resistance as described by the interviewees. For example, interviewees mentioned remaining silent about or outright opposing the frontline workers' aims to enhance the employability of a client. In the extract below, the interviewee participates in creating an untrustworthy resistant unemployed individual:

Then we have a few clients that we have nothing to offer. In Finnish [e.g., to be frank], this means that the person does not want to receive anything. They do not necessarily even continue as a jobseeker. They will move into being a client of social assistance. Unfortunately we have that type as well.... We have clients who tell the Public Employment Services the best version that looks good in their eyes, and to social services the one that looks good to their eyes. And they tell nothing to 
the Social Insurance Institution. They will only respond to what is asked, but otherwise they don't speak much. (Interview 1)

The interviewee begins by constructing a resistant position for a client who does not accept any employability services and who, due to a non-cooperative attitude, is often designated and 'parked' at other - primarily, social (and last resort) - services. Not much later, the interviewee elaborates upon this by describing a dishonest unemployed individual who intentionally misleads frontline workers and who remains resistant in his or her silence regarding personal aspirations.

Resistance is also associated with a non-compliant and a strong-willed attitude. In the following extract, the interviewee describes a resistant client who shows a forceful and negative attitude, which also serves as an obstacle to employability:

Some may say straight away that they will not go and do unpaid work. That some clients are very powerful and strong and say that they don't even try. At first they will ask how much is the rehabilitation benefit? And okay, it may be less than the unemployment benefit - well - it does not necessarily even need to be less. However, they will not even want less income if only by a little bit than they previously had. So, this is something that arises. These attitudes that clients have, they are kinds of barriers to rehabilitation and access to work. So these are something that I have to become aware of and become competent to handle with the client so that the client could be motivated. It's better not to trip over on these thoughts that clients express. (Interview 11)

In the extract above the interviewee constructs in her discourse a resistant long-term unemployed individual in need of persuasion. Therefore, within the resistant position, the unemployed individual does not immediately accept the ideas and proposals made or the advice given by frontline workers. Additionally, the resistant unemployed individual is described not only as being simultaneously aware of his or her own rights and possessing a critical mindset but also as someone who could be activated and 
motivated if the frontline worker is competent enough not to 'trip over on these thoughts that clients express'. Thus, the individual in a resistant position may be supported within this service regardless of any defiant attitudes related to employability enhancement.

Within the resistant position, the unemployed client is constructed as an actor unwilling to accept the assistance of becoming an employable subject. Therefore, frontline workers need to act as active and responsible agents themselves, for example, by adopting a persuasive approach in their work. The individual in a resistant position, therefore, may require control and gatekeeping skills amongst frontline workers (see also Romppainen et al. 2010, 607). Hence, the individual in a resistant position shows a non-ideal attitude and should be either 'left out' (i.e., 'parked') or activated, depending on how the resistance is tackled by frontline workers.

\section{Unfortunate}

The third position constructed through the employability discourse was the position of the unfortunate long-term unemployed individual. According to this position, the unemployed individual is portrayed as vulnerable, somewhat powerless and, therefore, in need of help and attention. The unemployed individual is both a victim of mistreatment and neglect by the welfare system as well as the target of general prejudice and stereotyping. In the unfortunate position, the unemployed individual has not enjoyed adequate access to services or is unable to use services due to illness or difficult life situations. Therefore, the individuals in the unfortunate position lack any real control over their situation and should not be obligated to take much responsibility for their own employability.

Regarding this position, I present the extracts that show both the strong activity and responsibility from the frontline workers' standpoint and in which the unfortunate 
position is constructed in relation and in resistance to the motivated, resistant and blameworthy positions. For the unemployed individual in the unfortunate position, previous experiences within the service system are described as negative and unreasonable, as illustrated here:

\begin{abstract}
Many might have had problems with their own municipality's social services or with healthcare centres. So nothing is examined when the situation has been the same for ten years. So then when one goes through this rehabilitation period and receives feedback in which it is recommended more strongly that certain extra medical examinations should be done. So, the practice has shown that then the person is taken seriously again and the rehabilitation or examinations are restarted. So a certain determination at that point, that now you shouldn't give up, when you are part of this gang. That now we will help you at this point, either towards working life or then towards pension/disability. (Interview 18)
\end{abstract}

In the extract above, the interviewee points out that the unfortunate long-term unemployed individual must be taken care of and helped by the welfare system and the professionals. Prior negative experiences and ignorance within the shattered service system have somewhat victimised the individual who was not taken seriously and did not receive the help and support he or she needed. In this extract, the frontline workers are portrayed as 'helpers', 'rule benders' and active agents who solve the 'un/employability' issue for the unemployed individual.

In fact, the interviewees stated that some in the unfortunate position should be on disability or given a diagnosis. Various illnesses and inabilities limit the long-term unemployed individual's agency within the labour market, functioning as the real explanation for a client's inability to attain a job. In the extract above, the interviewee contests the idea that unemployed individuals are positioned as blameworthy and lack an admirable motivated attitude. Rather, they should be perceived as misinterpreted: 
I emphasise the meaning of face-to-face meetings. Sometimes when a colleague recounts a situation it seems that the client is not willing to cooperate, the client is not motivated, nothing is found and things will not move forward and the picture looks very negative. And then when the client is met and talked to and somehow encountered, the client gains sufficient knowledge and information. So many times there will be motivation. ... It is thought that is due to a client's own unwillingness, lack of motivation, inefficiency, laziness. So that the client is a troublesome bloke. Many times it's been found that that isn't the case. It is more about the inability to handle their situation, sickness. These clients with neuropsychological problems. I would say that there are many - I don't know if I exaggerate - but working ability tests are bought from the Public Employment Services. So there has been a mild developmental disability for adults and quite many applications for pension/disability. Applications accepted for adult jobseekers who have received a diagnosis as an adult when it's been examined through this [joint] service. (Interview 32)

The interviewee starts by describing a situation in which the client is misunderstood and thought to be responsible for their situation due to their troublesome behaviour and attitude. Instead, the unemployed individual should be portrayed as someone with no real control over their situation, since illness exempts the unemployed individual from being responsible (see also Juhila, Hall and Raitakari 2010, 68, 70; Michailakis and Schirmer 2010). Instead of focussing on the undesirable behaviour and the shortcomings of an individual, empathy and understanding should prevail amongst frontline workers.

In terms of responsibility, an individual in an unfortunate position is granted the legitimate victim role and, therefore, granted limited room to act (see also Romppainen et al. 2010, 606), since he or she is constructed as somewhat weak, passive and helpless. The responsibility of the individual is to a certain extent rendered moot. Thus, action is requested from other actors instead of the unemployed individuals themselves because social structures constrain the action of an individual. The actual responsibility and 
moral duty of employability enhancement lies with the state and frontline workers who should adopt supportive and lenient approaches towards those in an unfortunate position who may, in fact, be 'unemployable'.

\section{Blameworthy}

The fourth and final position constructed through the employability discourse is that of the blameworthy long-term unemployed individual. This position situates 'unemployability' with the individual who is required to alter their disruptive behaviour and lifestyle in order to make them employable. In this position the unemployed individual is portrayed as intentionally avoiding both work and the status of an autonomous self-reliant individual. Thus, individuals in the blameworthy position are not taking their moral duty seriously due to their problematic behaviour.

To illustrate this position, I rely on two opposing extracts. The first provides a rather straightforward positioning of the blameworthy long-term unemployed individual. The second relies on a subtler positioning. In the following extract, the blameworthy position is constructed as an inability to participate in the labour market due to a lack of 'job-readiness':

But there are some social reasons whereby a person could work, but they are in no shape to. It is quite strongly connected to substance use and mental health problems. These are things that officials employ quite a lot. On the other hand - in my experience - when they [substance use and mental health problems] exist for years they [these people] have no time to go anywhere. So some part of the population we can't help until they themselves wake up. For example, those with substance misuse issues, one could get good treatment and support from health services. So they would need to wake up that something other than substance abuse should be done. So sometimes I feel frustrated in this job. Why do we need to pretend that we are trying and the client needs to appear that they are trying, even though we know this will lead nowhere? (Interview 26) 
In this extract the interviewee constructs the blameworthy unemployed individual as unwilling to use the services for their own good and shows very little hope of reengaging him or her in the labour market due to a problematic lifestyle. For the individual in a blameworthy position, different employability measures are not in place until a lifestyle change is internalised by the client. According to the interviewee, this requires 'waking up' as the problems 'rest' with the irresponsibly acting unemployed individual. The client in this example is portrayed as enterprising themselves in alcohol and drug consumption and unwilling to exercise responsible self-management and selfgovernance (Rose 2000, 331). Furthermore, the interviewee resists the responsibilisation expectations of both parties. Within this position, by constructing the unemployed individual as an actor making a choice, the blameworthiness is made visible (see Juhila, Hall and Raitakari 2010, 66).

In addition to morally disruptive behaviour, the unemployed individual in the blameworthy position does not understand their own best interests by giving excuses to frontline workers:

But if the client has been - so to speak - shirking lately. Being at home. It happens very easily in a person. Some say that they have never worked. It is said that a person can be institutionalised, but a person can also get stuck at home, so it will be difficult to leave anywhere and it is very stressful. That's why I've said to my clients that at first it feels very heavy and difficult, tiring. That all those existing pains will become worse, because the change in life is so drastic. By saying this, I have tried to make it clear that it is normal. Even an ordinary person who has been unemployed for a few months is in a stressful spot when looking for a new job. ... I also make it clear that every job has its difficulties. That working is not necessarily fun, but what it in essence causes, it can be great for well-being and improving one's life situation. Even though it initially feels that everything collapses. Each one of us does not always feel great pleasure and comfort here at work. Since otherwise work doesn't feel anything anymore and nothing feels anything, if it's only a pleasure. But one can feel satisfaction at work, and that 
brings a good feeling. Small things will build up, or make it entirely good. And then, if I find anything praiseworthy in a client, I will praise them. If one has an appearance that they can look like one of us, I have to bring it up. And if not, I must not bring it up, but dig something else then. (Interview 12)

The interviewee begins by adopting the language of scrounging when describing someone in a blameworthy position. The blameworthy unemployed individual should adopt a positive and realistic attitude towards work, which hints at an eroded work ethic as a barrier to employment. Thus, the interviewee adopts a pedagogical style when assisting long-term unemployed clients. In this sense, the client is not the sole agent in the storyline. Furthermore, at the end of the extract, the blameworthy position is constructed on the basis of a difference between the unemployed individual and the interviewee. The interviewee sets up 'us and them', locating the individual in the blameworthy position as belonging to "those who do not realise the necessities of a working life' and the interviewer and the interviewee as 'us responsible ordinary people' who appear praiseworthy.

Within the blameworthy position the long-term unemployed individual is responsibilised due to his or her irresponsibility and shortcomings, although without being described as someone with a resistant attitude. Frontline workers may play the role of the agent, but they have little room to manoeuvre and limited power to act until the unemployed individual assumes their responsibility in terms of employability enhancement. In this position the unemployed individual is not described as someone who should be disciplined and sanctioned but as someone who has very little hope of becoming employable due to their disruptive lifestyle and 'otherness'. Hence, the frontline workers legitimise either non-action or pedagogical forms of assistance. 


\section{Conclusion}

In conclusion, this study has provided analysis of how long-term unemployed individuals in Finland are positioned in frontline workers' interview talk. The analysis revealed four main positions constructed through employability discourse of motivated, resistant, unfortunate or blameworthy. Within these different positions, the responsibility related to employability enhancement was either shared, dependent on frontline workers, partly or mostly individualised. The results imply that responsibilities related to employability enhancement depends on how the client's job readiness, attitude and demeanour are constructed in the workers' discourse (see Rosenthal and Peccei 2006; Maynard-Moody and Musheno 2003; Lipsky 2010).

The vast majority of unemployed individuals was positioned as motivated and willing to show responsible attitude towards employability enhancement. The motivated position corresponds with the activity discourse that Romppainen et al. (2010) have identified when studying Finnish nurses' interview talk on unemployment. The individual in a motivated position has internalised the entrepreneurial properties such as commitment, having initiative and a willingness to pursue goals (see Dean 1995; Rose 2000; Garsten and Jacobsson 2004). This implies that even those long-term unemployed individuals who are rather remote from the labour market are expected to engage in self-development and entrepreneurial work on the self by maintaining an optimistic outlook, 'looking forward' and sharing their aspirations (Arts and van den Berg 2019). In previous studies these expectations have often been linked to those who are institutionally categorised as ‘job-ready’ (van der Berg and Arts 2019; Arts and van der Berg 2019; Haikkola 2019). 
However, this individualised responsibility regarding employability enhancement may also be exempted if one is positioned as unfortunate. Therefore, the results show that individualised responsibility of employability enhancement is both conformed to and resisted in frontline workers' interview talk. On the other end, those positioned as blameworthy are expected to take greater responsibility not only for their employability enhancement but also for their health, fitness and overall well-being (see Holmqvist 2009; Rose 2000; Dean 1995; Fejes and Berglund 2010). Therefore, the lack of employability and responsibility may be associated with opposing ends: noncommitment and disruptive lifestyle as well as helplessness and vulnerability, depending on how the long-term unemployed individual is positioned by the frontline workers.

Overall, my analysis reveals that the interviewees position themselves as responsible or not responsible for enhancing their long-term unemployed clients' employability depending on how employability or lack of it is constructed and a longterm unemployed individual is positioned. However, a large part of the responsibility for employability enhancement is portrayed as situated with the long-term unemployed individual. The analysis of positioning helps to identify frontline workers' orientation of work, that is, whether they provide their clients with encouragement, empathy, pedagogical advice (see van der Berg and Arts 2019; Marston, Larsen and McDonald 2005; Caswell et al. 2017) or 'parking' (see Romppainen et al. 2010). Therefore, these positions may be consequential and legitimise actions and non-actions towards individual long-term unemployed people and their position in the labour market (see also Garsten and Jakobsson 2004). In particular, to be positioned as resistant or blameworthy remains highly consequential because people may face, for example, a denial or a termination of employment services or be given a low priority within 
services (Michailaki and Schirmer 2010; Garsten and Jakobsen 2004; Romppainen et al. 2010).

Future research could examine to what extent unemployed individuals must present themselves as motivated and responsible or as unfortunate victims to be preferably positioned in the welfare services. Hence, future empirical work on positionings and employability could examine naturally occurring frontline interactions and activation encounters in Finland, focussing specifically on long-term unemployed individuals who are rather remote from the labour market. Such an approach may reveal, for example, how 'un-/employable' and 'un-/deserving' long-term unemployed subjects are both produced and contested in situ, and how unemployed individuals also participate as active agents in the interplay of positioning themselves and frontline workers (see also Raitakari et al. 2015; Eskelinen, Olesen and Caswell 2010).

\section{References}

Agllias, Kylie, Amanda Howard, Leanne Schubert, and Mel Gray. 2016. Australian Workers' Narratives about Emergency Relief and Employment Service Clients: Complex Issues, Simple Solutions. Australian Social Work 69 (3): 297-310.

Arts, Josien, and Marguerite Van Den Berg. 2019. Pedagogies of optimism: Teaching to 'look forward' in activating welfare programmes in the Netherlands. Critical Social Policy 39 (1): 66-86.

Broughton, Chad. 2003. Reforming poor women: the cultural politics and practices of welfare reform. Qualitative Sociology 26, 35-51. 
Caswell, Dorte, Flemming Larsen, Rik van Berkel, Kupka, Peeter. 2017. Conclusions and Topics for Future Research. In Frontline delivery of welfare-to-work policies in Europe. Activating the unemployed, edited by Rik van Berkel, Dorte Caswell, Peeter Kupka, and Flemming Larsen, 181-200. New York: Taylor \& Francis.

Cummins, Emily R., and Linda M. Blum. 2015. Suits To Self-Sufficiency": Dress for Success and Neoliberal Maternalism. Gender \& Society 29 (5): 623-646.

Davies, Bronwyn, and Rom Harré. 1990. Positioning: The Discursive Production of Selves. Journal for the Theory of Social Behaviour 20: 43-63.

Dean, Mitchell. 1995. Governing the unemployed self in an active society. Economy and Society 24 (4): 559-583.

Diedrich, Andreas, and Alexander Styhre. 2013. Constructing the employable immigrant: The uses of validation practices in Sweden. Ephemera: Theory \& Politics in Organization 13 (4): 759-783.

Eskelinen, Leena, Søren Peter Olesen, and Dorte Caswell. 2010. Client contribution in negotiations on employability - categories revised? International Journal of Social Welfare 19: 330-338.

Fejes, Andreas. 2010. Discourses on employability: constituting the responsible citizen. Studies in Continuing Education 32 (2): 89-102.

Fejes, Andreas, and Gun Berglund. 2010. Employability: significant signs of the present. Arbetsmarknad \& Arbetsliv 16 (2): 11-23.

Garsten, Christina, and Kerstin Jacobsson. 2004. Learning to Be Employable: An Introduction. In Learning to be employable, edited by Christina Garsten, and Kerstin Jacobsson, 1-22. Basingstoke: Palgrave Macmillan. 
Garsten, Christina, and Kerstin Jacobsson. 2013. Sorting people in and out: The plasticity of the categories of employability, work capacity and disability as technologies of government. Giving notice to employability. Ephemera: Theory \& Politics in Organization 13 (4): 825-850.

Harré, Rom, and Luk Langanhove. 1991. Varieties of Positioning. Journal for the Theory of Social Behaviour 21: 393-407.

Haikkola, Lotta. 2019. Shaping activation policy at the street level: Governing inactivity in youth employment services. Acta Sociologica 62 (3): 334-348.

Heino, Eveliina, and Laura Tarkiainen. 2019. Kelan työkykyneuvonnan työn kehykset työllistymistä edistävässä monialaisessa yhteispalvelussa. In Aktivointipolitiikkaa yhteisin palveluin: Näkökulmia työllistymistä edistävään monialaiseen yhteispalveluun, edited by Marketta Rajavaara, Anne Määttä, Riitta-Liisa Kokko, Laura Tarkiainen, 136 - 152. Helsinki: Kela.

Holmqvist, Mikael. 2009. Medicalization of unemployment: individualizing social issues as personal problems in the Swedish welfare state. Work, employment and society 23 (3): 405-421.

Howard, Amanda, Kylie Agllias, Leanne Schubert, Leanne, and Mel Gray. 2018. Hovering above the Stream: Perception, Experience and Identity at the Frontline of Work with Australian Unemployed Clients. International Social Work 61 (2): 219-233.

Juhila, Kirsi, Christopher Hall, and Suvi Raitakari. 2010. Accounting for the Clients' Troublesome Behaviour in a Supported Housing Unit: Blames, Excuses and Responsibility Professionals’ Talk. Journal of Social Work 10 (1): 59-79.

Karjalainen, Vappu, and Peppi Saikku. 2011. Governance of integrated activation policy in Finland. In The Governance of Active Welfare States in Europe, edited by Willibrord de Graa W, Rik Van Berkel, and Tomáš Sirowatka,, 216-236. Basingstoke: Palgrave. 
Lipsky, Michael. 2010. Street-Level Bureaucracy. Dilemmas of the Individual in Public Services. New York: Russell Sage Foundation.

L 1369/2014. Laki työllistymistä edistävästä monialaisesta yhteispalvelusta.

Marston Greg, Jørgen E Larsen, and Catherine McDonald, Catherine. 2005. The active subjects of welfare reform: A street-level comparison of employment services in Australia and Denmark. Social Work and Society 3 (2): 141-157.

Maynard-Moody, Steven, and Michael Musheno. 2003. Cops, Teachers, Counsellors: Stories from the Front Lines of Public Service. Ann Arbor: University of Michigan Press.

McDonald, Catherine, Greg Marston, and Amma Buckley. 2003. Risk Technology in Australia: The Role of the Job Seeker Classification Instrument in Employment Services. Critical Social Policy 23 (4): 498-525.

Michailakis, Dimitris, and Werner Schirmer. 2010. Agents of their health? How the Swedish welfare state introduces expectations of individual responsibility. Sociology of Health and Illness 32 (6): 930-47.

Minas, Renate. 2014. One-stop shops: Increasing employability and overcoming state fragmentation? International Journal of Social Welfare 23: S40-S53.

Purser, Gretchen W and Brian Hennigan. 2017. "Works as unto the Lord": Enhancing Employability in and Evangelical Job-Readiness Program. Qualitative Sociology 40: 111-133. 
Raitakari, Suvi, Sirpa Saario, Kirsi Juhila, and Kirsi Günther. 2015. Client participation in health: shifting positions in decision making. Nordic Social Work Research 5 (19): 35-49.

Rajavaara, Marketta, Anne Määttä, Riitta-Liisa Kokko and Laura Tarkiainen (eds.) . 2019. Aktivointipolitiikkaa yhteisin palveluin: Näkökulmia työllistymistä edistävään monialaiseen yhteispalveluun. Helsinki: Kela.

Romppainen, Katri, Rita Jähi, Antti Saloniemi, and Pekka Virtanen. 2010. Encounters with unemployment in occupational health care: Nurses' constructions of clients without work. Social Science \& Medicine 70: 605-608.

Rose, Nikolas. 2000. Government and control. British Journal of Criminology 40: 321399.

Rosenthal, Patrice A., and Riccardo Peccei. 2006. The social construction of clients by service agents in reformed welfare administration. Journal of Human Relations 59 (12): 1633-1658.

Saikku, Peppi, and Vappu Karjalainen. 2012. Network governance in activation policy health care as an emergent partner. International Journal of Sociology and Social Policy 32 (5/6): 299-311.

Seale, Elizabeth, Alison Buck, Kylie Parrotta. 2012. Who's to Blame? The Identity Talk of Welfare-To-Work Program Managers. Sociological Perspectives 55 (3): 501527.

Turgeon, Brianna, Tiffany Taylor, and Laura Niehaus. 2014. Contrast and classtalk: A critical discourse analysis of welfare-to-work programme managers. Discourse and Society 25 (5): 656-671. 
van den Berg, Marguerite, and Josien Arts. 2019. The Aesthetics of Work-Readiness: Aesthetic Judgements and Pedagogies for Conditional Welfare and Post-Fordist Labour Markets. Work, Employment and Society 33 (2), 298-313.

van Lagenhove, Luk, and Rom Harré. 1999. Introducing Positioning Theory. In Positioning Theory: Moral Context of Intentional Action Rom Harré, and Luk van Lagenhove, 14-31. Oxford: Blackwell Publishers.

Vesterberg, Viktor. 2013. Ethnicized un/employability: Problematized Others and the shaping of advanced liberal subjects. Ephemera: Theory \& Politics in Organization 13 (2): 737-757.

Woolford, Andrew, and Amanda Nelund. 2013. The responsibilities of the Poor: Performing Neoliberal Citizenship within the Bureaucratic Field. Social Service Review 87 (2): 292-318. 
Table 1. Table of the four main positions

\begin{tabular}{|c|c|c|c|c|}
\hline Positions & Motivated & Resistant & Unfortunate & Blameworthy \\
\hline $\begin{array}{l}\text { Long-term } \\
\text { unemployed } \\
\text { individuals as } \\
\text { agents }\end{array}$ & $\begin{array}{l}\text { Active } \\
\text { Forward- } \\
\text { looking } \\
\text { Close to } \\
\text { employment } \\
\text { Genuine will } \\
\text { to gain } \\
\text { employment }\end{array}$ & $\begin{array}{l}\text { Non- } \\
\text { committed } \\
\text { Negative } \\
\text { attitude and/or } \\
\text { silence } \\
\text { Opposing } \\
\text { employability } \\
\text { agenda }\end{array}$ & $\begin{array}{l}\text { Helpless } \\
\text { Vulnerable } \\
\text { Victimised } \\
\text { Misinterpreted }\end{array}$ & $\begin{array}{l}\text { Severe } \\
\text { problems } \\
\text { Disruptive } \\
\text { lifestyle } \\
\text { Remote from } \\
\text { labour market }\end{array}$ \\
\hline $\begin{array}{l}\text { Frontline } \\
\text { workers as } \\
\text { agents }\end{array}$ & $\begin{array}{l}\text { Encouraging } \\
\text { Providing } \\
\text { information, } \\
\text { time and } \\
\text { opportunities }\end{array}$ & $\begin{array}{l}\text { Persuading } \\
\text { Regulating }\end{array}$ & $\begin{array}{l}\text { Supporting } \\
\text { Solving } \\
\text { problems } \\
\text { Providing } \\
\text { empathy } \\
\text { Rule-bending }\end{array}$ & $\begin{array}{l}\text { Leaving alone } \\
\text { Providing } \\
\text { pedagogical } \\
\text { advice }\end{array}$ \\
\hline Responsibility & Shared & $\begin{array}{l}\text { Partly } \\
\text { individualised }\end{array}$ & $\begin{array}{l}\text { On frontline } \\
\text { workers }\end{array}$ & $\begin{array}{l}\text { Mostly } \\
\text { individualised }\end{array}$ \\
\hline
\end{tabular}

